\title{
Low-dose azathioprine is effective in maintaining remission among Chinese patients with Crohn's disease
}

\author{
Jianghong Wu', Yan Gao ${ }^{2}$, Chuanhua Yang ${ }^{1 *}$, Xueqing Yang ${ }^{3}$, Xuhang $\mathrm{Li}^{4}$ and Shudong Xiao ${ }^{1}$
}

\begin{abstract}
Background: Azathiopurine (AZA) is efficacious for maintenance remission of Crohn's disease (CD) at the standard dose of 2.0-2.5 mg/kg for Caucasian. It has been reported that the lower dose (1.0-2.0 mg/kg) in some Asian countries was as effective as the standard dose. In the present study we analyzed the efficacy of $<1.0 \mathrm{mg} / \mathrm{kg}$ AZA in maintaining remission for Chinese patients.

Methods: The clinical data of all CD patients were reviewed from 1993 to December 2012. The patients who initiated AZA treatment and were followed for $\geq 2$ years with complete medical data were included. We divided the patients into two groups according to their initial dose: $<1.0 \mathrm{mg} / \mathrm{kg}$ group and 1.0-2.0 mg/kg group.

Results: Among 77 patients, 39 (50.6\%) started treatment with $<1.0 \mathrm{mg} / \mathrm{kg} \mathrm{AZA}$ and 38 (49.4\%) with 1.0-2.0 mg/kg. The mean dose of $<1.0 \mathrm{mg} / \mathrm{kg}$ group remained under $1.0 \mathrm{mg} / \mathrm{kg}$ at 6,12 and 24 months, even if the doses were adjusted according to efficacy and tolerance. The remission rate in patients of $<1.0 \mathrm{mg} / \mathrm{kg}$ group was significantly higher than that in those of $1.0-2.0 \mathrm{mg} / \mathrm{kg}$ group $(P=0.025)$. A dose of $<1.0 \mathrm{mg} / \mathrm{kg} \mathrm{AZA}$ was more commonly associated with male gender, older age, heavier body weight and L1 location. Adverse events were observed in 21 of 77 patients (27.3\%) and no significant difference in occurrence of adverse events or leucopenia between two groups.
\end{abstract}

Conclusions: $<1.0 \mathrm{mg} / \mathrm{kg}$ AZA was effective as $1.0-2.0 \mathrm{mg} / \mathrm{kg}$ in maintaining remission among Chinese patients with $C D$.

Keywords: $<1.0$ mg/kg azathiopurine, Maintain remission, Crohn's disease, Chinese patients

\section{Background}

Crohn's disease $(\mathrm{CD})$ is an idiopathic chronic gastrointestinal inflammation of unknown etiology. Currently, the goal of treatment is to control disease activity by inducing and maintaining remission. In order to minimize occurrence of the associated complications or the need for surgery, patients have to take long-term medicines to control activity of disease and prevent relapse. For the maintenance of remission, immunomodulators (such as thiopurines and methotrexate) and anti-tumor necrosis factor-alpha monoclonal antibody have proven

\footnotetext{
*Correspondence: dryangch3@163.com

'Division of Gastroenterology and Hepatology, Ren Ji Hospital, School of medicine, Shanghai Jiao Tong University, Shanghai Institute of Digestive Disease; Key Laboratory of Gastroenterology \& Hepatology, Ministry of Health (Shanghai Jiao-Tong University), Shanghai, China

Full list of author information is available at the end of the article
}

to be highly efficient $[1,2]$. They not only decrease CD clinical activity but also heal the mucosa of ulcers and erosions $[3,4]$, reduce the need for corticosteroids, and improve the patient's quality of life. In Asian countries, particularly in developing countries such as China, antitumor necrosis factor-alpha monoclonal antibody therapy is very expensive, and most families can't afford it, because their health insurance doesn't cover this therapy [5]. Thus, cheaper and highly effective immunomodulators, particularly azathiopurine (AZA), are widely accepted as the firstline treatment by both patients and gastroenterologists. Although severe side effects may occur [6,7], AZA has been widely used globally for $\mathrm{CD}$ therapy.

In European patients, $2.0-2.5 \mathrm{mg} / \mathrm{kg}$ of AZA has been shown to be effective against CD [8], and $1.0 \mathrm{mg} / \mathrm{kg}$ of AZA has been confirmed to have no benefit [9]. However, 
in Japan, low doses (50-100 mg daily) of AZA are recommended because Japanese patients are more susceptible to dose-dependent adverse events [10]. Although a higher dose of AZA has been observed to produce better effects than a lower dose [11], it is not clear whether in Asian patients low-dose (50-100 mg daily) AZA is as effective as the standard dose for long-term maintenance of remission. In China, where the incidence of $\mathrm{CD}$ is rapidly rising, the number of patients dependent on immunomodulators has increased over the years [12]. In the present study, we reviewed of all CD patients who underwent AZA therapy at our medical center and analyzed the efficacy and tolerance of AZA.

\section{Methods}

\section{Patients population}

The clinical data of CD patients from 1993 to December 2012 in Ren Ji Hospital, Shanghai Jiao Tong University School of Medicine, Shanghai Institute of Digestive Disease were reviewed. The diagnosis of CD was made based on clinical, endoscopic, histopathological, radiological findings and at least 6 months follow-up [13]. The patients who received AZA treatment and were followed for $\geq 2$ years were screened. Patients were excluded if 1) their medical data or follow-up data were not complete; 2) they received anti-tumor necrosis factor-alpha monoclonal antibody therapy for inducing remission within three months before/after AZA therapy. The disease activity was assessed by the Harvey and Bradshow Index (HBI). Data regarding dosage, concomitant medications, body weight, HBI, duration of remission, efficacy and adverse events were collected from the medical record or follow-up.

\section{The decision for using AZA}

The decisions of administrating AZA were: 1) frequent relapse; 2) gastrointestinal stricture/obstruction; 3) fistulizing CD; 4) prevention of postoperative recurrence; 5) steroidsparing agent for steroid-dependent or steroid-refractory; 6) moderate to severe $C D$. Clinical relapse was defined as $\mathrm{HBI}>4$ or need for re-introduce of steroids or occurrence of new complications. Frequent relapse was defined as $\geq 2$ relapses within 1 year. Steroid-dependence was defined as relapse after the dosage of steroids tapered to $10 \mathrm{mg}$ or relapse within three months after steroids sparing. Steroidrefractory was defined as no response towards full dose of steroids for four weeks.

\section{Treatment strategies}

The patients, who were prescribed with AZA, were monitored for full blood count once a week and liver function tests every 2 weeks within 4 weeks at the start of therapy, and monthly thereafter. The efficacy was evaluated every three months.

\section{The definition of efficacy and toxicity}

Remission was defined as $\mathrm{HBI} \leq 4$ or a decrease of at least 2 of HBI. Leucopenia was defined as white blood cell count less than $3 \times 10^{9} / 1$ (normal range: $4 \times 10^{9} / 1-10 \times 10^{9} / 1$ ); Thrombocytopenia was defined as platelet count less than lower border of normal range $\left(<100 \times 10^{9} / \mathrm{l}\right)$. Hepatic injury was defined as a liver function test above the normal range.

\section{Statistics}

Doses were presented as mean \pm SD. Remission rates were expressed as a proportion with 95\% confidence interval (CI). The decisions for AZA treatment and withdrawn were compared by chi-square. Clinical characteristics between groups were analyzed by Student's $t$-test, chi-square, or Mann-Whitney $U$-test. Probabilities of constant remission or off-steroid remission were calculated using the Kaplan-Meier statistical method and tested using Log-rank test. A 2 -sided $P$-value $<0.05$ was considered statistically significance.

\section{Results}

In all, the data of $99 \mathrm{CD}$ patients who started AZA treatment before December 2010 were investigated. Twenty-two patients were excluded: $8(8.1 \%)$ due to the lack of complete medical records or follow-up data and $14(14.1 \%)$ due to concomitant anti-tumor necrosis factor-alpha monoclonal antibody therapy within 3 months of AZA therapy. Finally, 77 patients who met the inclusion criteria were included in our study: 54 were male and 23 female. The mean age at the start of AZA treatment was 32.2 years (range, 15-68 years). The mean duration from diagnosis to AZA treatment was 27.6 months (range, 0-240 months). Twenty-eight patients $(36.4 \%)$ had undergone abdominal operations prior to AZA treatment. Age at diagnosis, disease behavior and location were categorized according to the Montreal classification [14]: 30 (39.0\%), 10 (13.0\%), $35(45.5 \%)$, and $15(19.5 \%)$ patients were classified as L1 (ileum), L2 (colon), L3 (ilecolon), and L4 (upper gastrointestinal tract) respectively; and 33 (42.9\%), 40 (51.9\%), 7 (9.1\%), and $24(31.2 \%)$ patients were classified as B1 (nonstricturing, nonpenetrating), B2 (stricturing), B3 (penetrating), and $\mathrm{p}$ (perianal disease) respectively. The decisions for using AZA were summarized (Table 1).

\section{Dose of AZA}

Seventy-four patients (96.1\%) started treatment with $50 \mathrm{mg} / \mathrm{d}$ of AZA, two (2.6\%) with $75 \mathrm{mg} / \mathrm{d}$, and one (1.3\%) with $25 \mathrm{mg} / \mathrm{d}$. The doses of AZA were adjusted according to efficacy and tolerance (Table 2). Significantly higher doses were administered in patients who didn't achieve remission compared to those who achieved remission at 12 months $(1.4 \pm 0.4$ versus $0.9 \pm 0.2 \mathrm{mg} / \mathrm{kg}$; 
Table 1 Decisions for using azathioprine

\begin{tabular}{|c|c|c|c|c|}
\hline Decisions & $\begin{array}{l}\text { All Patients with AZA } \\
\qquad(\mathrm{n}=77)\end{array}$ & $\begin{array}{c}<1.0 \mathrm{mg} / \mathrm{kg} \text { group } \\
(\mathrm{n}=39)\end{array}$ & $\begin{array}{c}1.0-2.0 \mathrm{mg} / \mathrm{kg} \text { group } \\
(\mathrm{n}=38)\end{array}$ & $P$-value \\
\hline Gastrointestinal stricture/obstruction & 37 & 19 & 18 & 0.854 \\
\hline Fistulizing CD & 22 & 10 & 12 & \\
\hline Frequent relapse & 15 & 8 & 7 & \\
\hline Moderate to severe CD & 10 & 4 & 6 & \\
\hline Prevention of postoperative recurrence & 6 & 2 & 4 & \\
\hline Steroid-sparing agent for steroid-dependent or steroid-refractory & 6 & 4 & 2 & \\
\hline
\end{tabular}

18 cases contained more than one decision.

$A Z A$ azathioprine, $C D$ Crohn's Disease.

$P=0.009)$ and 24 months $(1.2 \pm 0.5$ versus $1.0 \pm 0.2 \mathrm{mg} /$ $\mathrm{kg} ; P=0.005)$, but not at 6 months $(1.0 \pm 0.2$ versus $1.0 \pm$ $0.3 \mathrm{mg} / \mathrm{kg} ; P=0.828$ ). In our cohort, almost half the patients were treated with $<1.0 \mathrm{mg} / \mathrm{kg}$ AZA. According to their initial dose, we divided the patients into two groups: $<1.0 \mathrm{mg} / \mathrm{kg}$ group and $1.0-2.0 \mathrm{mg} / \mathrm{kg}$ group.

Within 2 years, the doses of six patients in each group were adjusted: in $<1.0 \mathrm{mg} / \mathrm{kg}$ group, four were increased and two decreased, and in 1.0-2.0 mg/ $/ \mathrm{kg}$ group, five were increased and one decreased. The mean dose of $<1.0 \mathrm{mg} / \mathrm{kg}$ group remained under $1.0 \mathrm{mg} / \mathrm{kg}$ during the 2 years, and a significant difference was found between the two groups (Figure 1).

\section{Efficacy of AZA treatment}

The effect of AZA treatment was first evaluated at 6 months because remission was induced by corticosteroids in 62 patients $(80.5 \%)$, and the doses of corticosteroids were continuously tapered during 3-6 months at the start of AZA treatment. The overall remission rates of all 77 patients at $0,6,12$, and 24 months were $7.8 \%$ (95\% CI, 3.2\%-16.8\%), 70.1\% (95\% CI, 58.5\%-79.8\%), $53.2 \%$ (95\% CI, 41.6\%-64.6\%), and 35.1\% (95\% CI, $24.8 \%-46.9 \%)$ respectively. The percentage of patients who continued taking AZA at 6, 12, and 24 months were $75.3 \%$ (95\% CI, 64.0\%-84.1\%), 61.0\% (95\% CI, 49.2\%-71.7\%), and 50.6\% (95\% CI, 39.1\%-62.1\%) respectively, and their remission rates were 93.1\% (95\% CI, 82.5\%-97.8\%), $87.2 \%$ (95\% CI, 73.6\%-94.7\%), and 69.2\% (95\% CI, 52.3\%-82.5\%) respectively. When remission was achieved in relapsed patients after adjusting the treatment regimens, the remission rates were 93.1\% (95\% CI, 82.5\%-97.8\%), 93.6\% (95\% CI, 81.4\%-98.3\%), and $92.3 \%$ (95\% CI, 78.0\%-98.0\%) respectively; the overall remission rates of 77 patients at 6, 12, and 24 months were $70.1 \%$ (95\% CI, 58.5\%-79.8\%), 57.1\% (95\% CI, $45.4 \%-68.2 \%$ ), and $46.8 \%$ (95\% CI, 35.4\%-58.4\%) respectively. A significant difference was observed in the remission rates of the $<1.0 \mathrm{mg} / \mathrm{kg}$ group and $1.0-2.0 \mathrm{mg} / \mathrm{kg}$ group $(P=0.0259)$ (Figure 2), and a significant difference was also observed in the off-steroid remission rates between two groups $(P=0.0120)$. The decisions for using AZA and the reasons for withdrawal of treatment were listed and no significant difference was found between the two groups (Tables 1 and 3).

\section{Putative factors associated with low-dose AZA $(<1.0 \mathrm{mg} / \mathrm{kg})$}

In our cohort, there were more male patients in $<1.0 \mathrm{mg} / \mathrm{kg}$ group than in $1.0-2.0 \mathrm{mg} / \mathrm{kg}$ group $(P=0.005)$. The mean body weight was significantly greater in $<1.0 \mathrm{mg} / \mathrm{kg}$ group than in $1.0-2.0 \mathrm{mg} / \mathrm{kg}$ group $(P<0.001)$. In addition patients in $<1.0 \mathrm{mg} / \mathrm{kg}$ group were older (35.5 years old) than those in $1.0-2.0 \mathrm{mg} / \mathrm{kg}$ group (28.7 years old) $(P=0.011)$, although there was no significant difference in age at diagnosis according to the Montreal classification. Locations significantly differed between the two groups $(P<0.001)$ : L3 was more prevalent in $1.0-2.0 \mathrm{mg} / \mathrm{kg}$ group, while L1 was more prevalent in $<1.0 \mathrm{mg} / \mathrm{kg}$ group (Table 4 ).

\section{Adverse events}

Adverse events were observed in 21 of 77 patients (27.3\%), due to which 14 (18.2\%) discontinued AZA therapy (Table 5). Leucopenia occurred in 8 patients (10.4\%), of whom three discontinued therapy. Infection occurred in 2 patients (2.6\%) (One suffered from perianal fistula infected

Table 2 Doses $(\mathrm{mg} / \mathrm{kg}$ ) of azathioprine at different time points

\begin{tabular}{lccccc}
\hline & Mean dose & Range dose & Patients with $<\mathbf{1 . 0} \mathbf{~ m g / k g}$ & Patients with $\mathbf{1 . 0 - 2 . 0} \mathbf{~ m g / k g}$ & Patients with $>\mathbf{2 . 0} \mathbf{~ m g / \mathbf { k g }}$ \\
\hline Initial & $1.0 \pm 0.2$ & $0.6-1.6$ & $39(50.6 \%)$ & $38(49.4 \%)$ & 0 \\
6 Month & $1.0 \pm 0.3$ & $0.4-1.7$ & $29(50.0 \%)$ & $29(50.0 \%)$ & 0 \\
12 Month & $1.0 \pm 0.3$ & $0.4-1.9$ & $24(51.1 \%)$ & $23(48.9 \%)$ & 0 \\
24 Month & $1.1 \pm 0.3$ & $0.4-2.1$ & $17(43.6 \%)$ & $21(53.9 \%)$ & $1(2.6 \%)$ \\
\hline
\end{tabular}




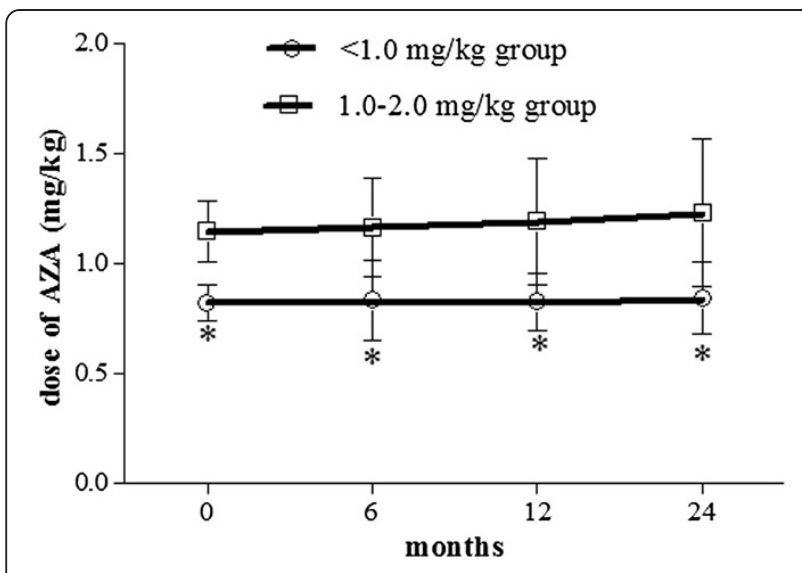

Figure 1 Dose of azathioprine in $<1.0 \mathrm{mg} / \mathrm{kg}$ group and 1.0-2.0 $\mathrm{mg} / \mathrm{kg}$ group at different time points. The patients treated with AZA were divided into $<1.0 \mathrm{mg} / \mathrm{kg}$ group and $1.0-2.0 \mathrm{mg} / \mathrm{kg}$ group according to their initial dose. The doses of AZA were adjusted according to efficacy and tolerance during the 2-year period. The mean dose of $<1.0 \mathrm{mg} / \mathrm{kg}$ group remained under $1.0 \mathrm{mg} / \mathrm{kg}$. ${ }^{*} P<0.01$ compared the dose of $<1.0 \mathrm{mg} / \mathrm{kg}$ group with $1.0-2.0 \mathrm{mg} / \mathrm{kg}$ group.

by Staphylococcus and AZA therapy was discontinued after recovery by the patient's choice; another suffered from urinary tract infection). However, no significant difference was observed in the occurrence of adverse events or leucopenia between $<1.0 \mathrm{mg} / \mathrm{kg}$ group and 1.0$2.0 \mathrm{mg} / \mathrm{kg}$ group (Table 4 ).

\section{Discussion}

In Europe and the United States, the dose of AZA for effective induction and maintenance of remission, as recommended by consensus, is $2.0-2.5 \mathrm{mg} / \mathrm{kg}[1,8]$. A previous study has shown that for the majority of Koreans, low-dose AZA (1.35 mg/kg, 105 patients) for remission induction of inflammatory bowel disease was as effective as the standard dose $(2.25 \mathrm{mg} / \mathrm{kg}, 17$ patients $)$, and $0.94-1.68 \mathrm{mg} / \mathrm{kg}$ was effective for $\mathrm{CD}$ maintenance.

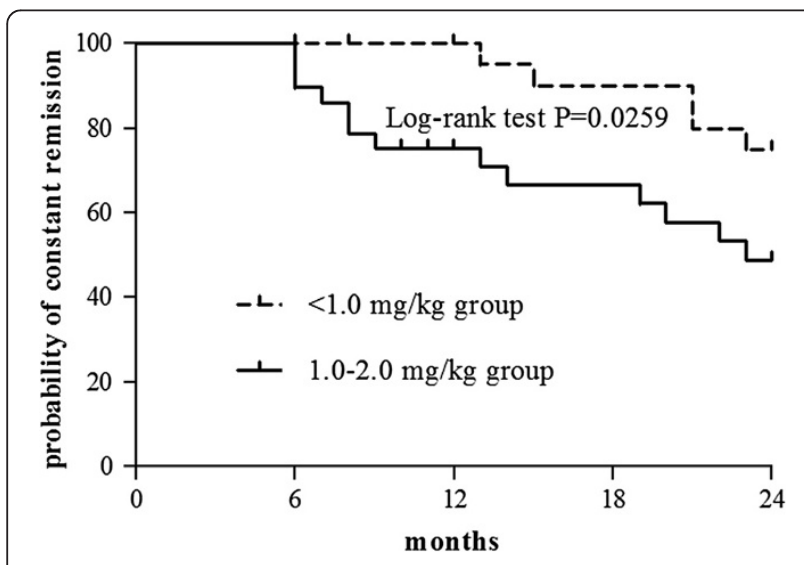

Figure 2 Cumulative probabilities of constant remission during 24 months using Kaplan-Meier statistical method.
Table 3 Causes for withdrawal of azathioprine treatment

\begin{tabular}{|c|c|c|c|c|}
\hline Causes & $\begin{array}{c}\text { All Patients } \\
\text { with AZA }\end{array}$ & $\begin{array}{c}<1.0 \mathrm{mg} / \mathrm{kg} \\
\text { group }\end{array}$ & $\begin{array}{c}1.0-2.0 \mathrm{mg} / \mathrm{kg} \\
\text { group }\end{array}$ & $P$-value \\
\hline Adverse events & 14 & 10 & 4 & 0.101 \\
\hline No response & 3 & 0 & 3 & \\
\hline Relapse & 1 & 1 & 0 & \\
\hline Patients' intention & 20 & $10^{\Delta}$ & $10^{\Delta}$ & \\
\hline Total & 38 & 21 & 17 & \\
\hline
\end{tabular}

${ }^{\Delta}$ Four patients were aware of their white blood cells count $<4 \times 10^{9} /$ l and $>3 \times 10^{9} / \mathrm{l}$ ), and discontinued AZA therapy by their own choices. $A Z A$ azathioprine.

However, almost all patients in the low-dose group developed leucopenia or neutropenia, indicating that the doses were too strong for the patients [15]. In Japan, $0.6-1.2 \mathrm{mg} /$ $\mathrm{kg}$ AZA was prescribed for patients with ulcerative colitis, but only 17 out of $22(77.3 \%)$ patients completed that 6month trial [16]. These reports suggest that in eastern Asia, the suitable dose of AZA is much lower than the standard, and that the effect of a $<1.0 \mathrm{mg} / \mathrm{kg}$ dose of AZA for maintenance of remission is limited. In the present study on Chinese patients, the mean doses at 6,12 , and 24 months were $1.0,1.0$, and $1.1 \mathrm{mg} / \mathrm{kg}$ respectively, and almost half the patients were treated with $<1.0 \mathrm{mg} / \mathrm{kg}$ AZA. The efficacy of $\sim 1.0 \mathrm{mg} / \mathrm{kg}$ AZA in maintaining remission of $C D$ was confirmed. Next, we compared the effect of $<1.0 \mathrm{mg} / \mathrm{kg}$ AZA with that of $1.0-2.0 \mathrm{mg} / \mathrm{kg}$ AZA at 24 months, based on our previous result that the severity of disease remained unaltered in $90 \%$ patients with $\mathrm{CD}$ during the 2-year period [17]. To our surprise, the remission rate in patients of $<1.0 \mathrm{mg} / \mathrm{kg}$ group was significantly higher than that in those of $1.0-2.0 \mathrm{mg} / \mathrm{kg}$ group. To explain this unexpected result, we further analyzed the factors associated with $<1.0 \mathrm{mg} / \mathrm{kg}$ group.

At our medical center, the doses of AZA were adjusted according to efficacy and tolerance, and the doses of patients who did not achieve remission were significantly higher than those of patients who achieved remission at 12 and 24 months. We do not know whether the need-based escalation of doses in $<1.0 \mathrm{mg} / \mathrm{kg}$ group reached $\geq 1.0 \mathrm{mg} / \mathrm{kg}$. The doses of six patients in each group were adjusted: in $<1.0 \mathrm{mg} / \mathrm{kg}$ group, four were increased and two decreased, and in $1.0-2.0 \mathrm{mg} / \mathrm{kg}$ group, five were increased and one decreased. The mean AZA dose of $<1.0 \mathrm{mg} / \mathrm{kg}$ group remained under $1.0 \mathrm{mg} /$ $\mathrm{kg}$ during the 2-year period, and was lower than that of $1.0-2.0 \mathrm{mg} / \mathrm{kg}$ group. Since the remission rate increased after treatment regimens were adjusted, we were unable to determine whether the patients discontinued AZA treatment or whether the decisions for using AZA influenced dose adjustment. No significant differences were observed between the two groups with regard to the causes for withdrawal of AZA treatment and the decisions for using AZA. Adverse events were the main reason for AZA 
Table 4 Characteristics of patients between $<1.0 \mathrm{mg} / \mathrm{kg}$ group and $1.0-2.0 \mathrm{mg} / \mathrm{kg}$ group

\begin{tabular}{|c|c|c|c|c|}
\hline Type & $\begin{array}{l}\text { All Patients with AZA } \\
\qquad(n=77)\end{array}$ & $\begin{array}{c}<1.0 \mathrm{mg} / \mathrm{kg} \text { group } \\
(\mathrm{n}=39)\end{array}$ & $\begin{array}{c}1.0-2.0 \mathrm{mg} / \mathrm{kg} \text { group } \\
(\mathrm{n}=38)\end{array}$ & $P$-value \\
\hline \multicolumn{5}{|l|}{ Gender } \\
\hline Male & 54 & 33 & 21 & \multirow[t]{2}{*}{0.005} \\
\hline Female & 23 & 6 & 17 & \\
\hline Age at AZA treatment & 32.2 & 35.5 & 28.7 & 0.011 \\
\hline Duration from diagnosis to AZA treatment & 27.6 & 25.7 & 29.5 & 0.683 \\
\hline \multicolumn{5}{|l|}{ Age at diagnosis } \\
\hline $\mathrm{A} 1$ & 5 & 2 & 3 & \multirow[t]{3}{*}{0.112} \\
\hline $\mathrm{A} 2$ & 59 & 27 & 32 & \\
\hline A3 & 13 & 10 & 3 & \\
\hline \multicolumn{5}{|l|}{ Location } \\
\hline L1 & 30 & 24 & 6 & \multirow[t]{4}{*}{$<0.001$} \\
\hline L2 & 10 & 5 & 5 & \\
\hline L3 & 35 & 9 & 26 & \\
\hline$\llcorner 4$ & 15 & $9^{*}$ & $6^{*}$ & \\
\hline \multicolumn{5}{|l|}{ Behavior } \\
\hline $\mathrm{B} 1$ & 33 & 19 & 14 & \multirow[t]{4}{*}{0.342} \\
\hline B2 & 40 & 19 & 21 & \\
\hline B3 & 7 & $2^{\#}$ & $5^{\#}$ & \\
\hline$P$ & 24 & 11 & 13 & \\
\hline \multicolumn{5}{|l|}{ Surgery history } \\
\hline Yes & 28 & 15 & 13 & \multirow[t]{2}{*}{0.698} \\
\hline No & 49 & 24 & 25 & \\
\hline Initial HBI & 5.0 & 4.8 & 5.1 & 0.624 \\
\hline Initial body weight (kg) & 52.9 & 60.5 & 45.2 & $<0.001$ \\
\hline \multicolumn{5}{|l|}{ Concomitant with 5-ASA/SASP } \\
\hline \multicolumn{5}{|l|}{ At initial } \\
\hline Yes & 50 & 29 & 21 & \multirow[t]{2}{*}{0.079} \\
\hline No & 27 & 10 & 17 & \\
\hline \multicolumn{5}{|l|}{ At month 24} \\
\hline Yes & 17 & 9 & 8 & \multirow[t]{2}{*}{0.455} \\
\hline No & 22 & 9 & 13 & \\
\hline \multicolumn{5}{|l|}{ Adverse events } \\
\hline Yes & 21 & 13 & 8 & \multirow[t]{2}{*}{0.226} \\
\hline No & 56 & 26 & 30 & \\
\hline \multicolumn{5}{|l|}{ Leucopenia } \\
\hline Yes & 8 & 4 & 4 & \multirow[t]{2}{*}{1.000} \\
\hline No & 69 & 35 & 34 & \\
\hline
\end{tabular}

*Including L4 coexist with L1or L3.

\#Including B3 coexist with B2.

$P$ for difference between $<1.0 \mathrm{mg} / \mathrm{kg}$ group and $1.0-2.0 \mathrm{mg} / \mathrm{kg}$ group.

$A Z A$ azathioprine, HBI Harvey and Bradshow Index, 5-ASA 5-aminosalicylic acid, SASP sulfasalazine.

withdrawal and they hindered dose escalation. No significant difference was observed with respect to the occurrence of adverse events or leucopenia between the two groups. In vivo, when AZA was concomitantly administered with 5-aminosalicylic acid sulfasalazine (5-ASA/ SASP), the level of 6-thioguanine nucleotide significantly 
Table 5 Adverse events of azathioprine in 77 Patients

\begin{tabular}{lccc}
\hline Type & $\begin{array}{c}\text { Adverse } \\
\text { events }\end{array}$ & $\begin{array}{c}\text { AZA } \\
\text { withdrawal }\end{array}$ & $\begin{array}{c}\text { Concomitant with } \\
\text { 5-ASA/SASP }\end{array}$ \\
\hline Leucopenia & 8 & 3 & 3 \\
Hepatic Injury & 7 & 5 & 4 \\
Thrombocytopenia & 1 & 1 & 1 \\
Pancreatitis & 1 & 1 & 1 \\
Infection & $2^{\varphi}$ & 1 & 1 \\
Rash of Skin & 1 & 1 & 1 \\
Discomfort of & 1 & 1 & 0 \\
Stomach & 1 & 1 & 1 \\
Fatigue & 22 & 14 & 12 \\
Total & & & \\
\hline
\end{tabular}

${ }^{\varphi}$ Including both leucopenia and infection occurred in one patient. 5-ASA 5-aminosalicylic acid, SASP sulfasalazine.

increased with high occurrences of leucopenia [18]. We hypothesize that the concomitant administration of 5-ASA/SASP may be related to the lower dose AZA. In the present study, no significant difference was found with regard to the concomitant use of 5-ASA/SASP between the two groups at 0 and 24 months. Adverse events were not significantly affected by the concomitant administration of 5-ASA/SASP between the groups.

Our results indicated that a dose of $<1.0 \mathrm{mg} / \mathrm{kg}$ AZA was more commonly associated with male gender, older age, heavier body weight, and L1 location. Male gender has been identified as a factor for long-term remission $[19,20]$, and in the present study it was also related with low-dose AZA $(<1.0 \mathrm{mg} / \mathrm{kg})$. On the other hand, higher rates of relapse were seen in female patients; their doses of AZA had to be escalated. Older age was another factor for long-term remission and young patients were prone to be disabling CD [17,19-21]. Patients in $<1.0 \mathrm{mg} / \mathrm{kg}$ group were significantly older than those in $1.0-2.0 \mathrm{mg} / \mathrm{kg}$ group at the start of AZA therapy, and the age (35.5 years) was almost the same as that reported by Fraser AG et al., who observed a lower relapse rate in the patients above 36 years of age [19]. Heavier body weight was also related with low-dose AZA $(<1.0 \mathrm{mg} / \mathrm{kg})$. In fact, the patients with heavier body weight suggested CD did not markedly influence the health of patients. In the previous reports, location had no significant effect on the treatment of AZA, except for colon, which was implicated to be associated with remission $[19,20]$. In our cohort, only $10(13.0 \%)$ patients were classified as L2, L1 (39.0\%) and L3 (45.5\%) were the majority. Significant differences were seen with regard to the locations between two groups: L3 was more prevalent in $1.0-2.0 \mathrm{mg} / \mathrm{kg}$ group, while L1 was more prevalent in $<1.0 \mathrm{mg} / \mathrm{kg}$ group. It is plausible that patients with larger extent of disease required higher dose of AZA to maintain remission. Overall, male gender, older age, heavier body weight, and L1 location were associated with long-term remission using $<1.0 \mathrm{mg} / \mathrm{kg}$ AZA.

Leucopenia (white blood cells count $<3 \times 10^{9} / \mathrm{l}$ ) has been reported to occur in $20-30 \%$ patients taking $2.0-2.5 \mathrm{mg} / \mathrm{kg}$ AZA [22]. In the present study, leucopenia occurred in $10.4 \%$ patients. In fact, a white blood cell count of $<4 \times$ $10^{9} / 1$ was seen in $24.7 \%$ patients. If the patients were aware of their low white blood cell counts $\left(<4 \times 10^{9} / 1\right.$ and $\left.>3 \times 10^{9} / 1\right)$, they would have discontinued AZA therapy by their own choices (eight patients in the present study). Since there was no difference in the relapse rates between leucopenic and non-leucopenic patients, we did not escalate the dose up to development of leucopenia [15]. Our principle of prescription was to adjust the dose of AZA according to the white blood cell count and HBI: if HBI was $<4$ and AZA was well tolerated, the same dose of AZA was continued. We believed that some patients in our cohort were capable of tolerating higher doses of AZA, but chose not to because their HBI was $<4$ and they were satisfied with the therapy. Our patients' wishes were always respected. Thus, the principles of prescription practiced by our medical center also contributed to the lower dose AZA.

Our results showed that in approximately half the patients with $\mathrm{CD}$, low-dose AZA $(<1.0 \mathrm{mg} / \mathrm{kg})$ proved efficient for the maintenance of remission and the principles of prescription applied by our medical center was suitable. In Europe and in the United States, the dose of AZA for CD patients is escalated every 2 weeks until the target dose of $2.0-2.5 \mathrm{mg} / \mathrm{kg}$ is reached [23]. Western and Eastern countries differ not only in the manifestations of $\mathrm{CD}$ but also with regards to its treatment $[12,24]$. The limitations of this study are its small sample size, retrospective nature and single-center design. A previous report found that $2.0 \mathrm{mg} / \mathrm{kg}$ AZA was well tolerated by 11 of 13 Chinese patients [25] and that Singapore Asians could tolerate $1.95 \mathrm{mg} / \mathrm{kg}$ AZA [26]. These results suggest that a prospective, multicenter, large clinical trial is necessary to confirm the efficacy of $<1.0 \mathrm{mg} / \mathrm{kg}$ AZA for long-term maintenance of remission in Chinese patients with $\mathrm{CD}$.

\section{Conclusions}

In summary, in Chinese patients with CD, low-dose AZA $(<1.0 \mathrm{mg} / \mathrm{kg})$ may be effective for the maintenance of remission, and dose adjustment should be individualized according to efficacy and adverse events.

\section{Abbreviations}

AZA: Azathiopurine; CD: Crohn's disease; HBI: Harvey and Bradshow Index; SASP: Sulfasalazine; 5-ASA: 5-aminosalicylic acid.

\section{Competing interests}

The authors declare that they have no competing interests. 


\section{Authors' contributions}

JW was responsible for acquisition of data, analysis, and preparing the manuscript. $Y G$ and $X Y$ were assisted in acquisition of data and drafting the manuscript. $X \mathrm{~L}$ and $\mathrm{SX}$ were involved in discussion and revised the manuscript. CY was responsible for design, analysis and interpretation of data. All authors have read and approved the final manuscript.

\section{Acknowledgements}

This work was supported by National Natural Science Foundation of China (30570829 and 81370509).

\section{Author details}

'Division of Gastroenterology and Hepatology, Ren Ji Hospital, School of medicine, Shanghai Jiao Tong University, Shanghai Institute of Digestive Disease; Key Laboratory of Gastroenterology \& Hepatology, Ministry of Health (Shanghai Jiao-Tong University), Shanghai, China. ${ }^{2}$ Division of Gastroenterology and Hepatology, Tengzhou Central People's Hospital, Tengzhou, China. ${ }^{3}$ Division of 2008 undergraduate, Anhui Medical University, Hefei, China. ${ }^{4}$ Department of Medicine GI Division, Johns Hopkins University School of Medicine, Baltimore, USA.

Received: 24 May 2013 Accepted: 24 September 2013

Published: 27 September 2013

\section{References}

1. Mowat C, Cole A, Windsor A, Ahmad T, Arnott I, Driscoll R, Mitton S, Orchard T, Rutter M, Younge L, Lees C, Ho GT, Satsangi J, Bloom S; IBD section of the British society of gastroenterology: Guidelines for the management of inflammatory bowel disease in adults. Gut 2011, 60:571-607.

2. Prefontaine E, Sutherland LR, Macdonald JK, Cepoiu M: Azathioprine or 6mercaptopurine for maintenance of remission in Crohn's disease. Cochrane Database Syst Rev 2009, 21:CD000067.

3. D'Haens G, Geboes K, Rutgeerts P: Endoscopic and histologic healing of Crohn's (ileo-) colitis with azathioprine. Gastrointest Endosc 1999, 50:667-671.

4. D'Haens G, Geboes K, Ponette E, Penninckx F, Rutgeerts P: Healing of severe recurrent ileitis with azathioprine therapy in patients with Crohn's disease. Gastroenterology 1997, 112:1475-1481.

5. Rogler G, Bernstein CN, Sood A, Goh KL, Yamamoto-Furusho JK, Abbas Z, Fried M: Role of biological therapy for inflammatory bowel disease in developing countries. Gut 2012, 61:706-712.

6. Camus M, Seksik P, Bourrier A, Nion-Larmurier I, Sokol H, Baumer P, Beaugerie L, Cosnes J: Long-term outcome of patients with Crohn's disease Who respond to azathioprine. Clin Gastroenterol Hepatol 2013, 11:389-394.

7. Lewis JD, Schwartz JS, Lichtenstein GR: Azathioprine for maintenance of remission in Crohn's disease: benefits outweigh the risk of lymphoma. Gastroenterology 2000, 118:1018-1024.

8. Dignass A, Van Assche G, Lindsay JO, Lémann M, Söderholm J, Colombel JF, Danese S, D'Hoore A, Gassull M, Gomollón F, Hommes DW, Michetti P, O'Morain C, Oresland T, Windsor A, Stange EF, Travis SP, European Crohn's and Colitis Organisation (ECCO): The second European evidence-based consensus on the diagnosis and management of Crohn's disease: current management. J Crohns Colitis 2010, 4:28-62.

9. Summers RW, Switz DM, Sessions JT Jr, Becktel JM, Best WR, Kern F Jr, Singleton JW: National cooperative Crohn's disease study: results of drug treatment. Gastroenterology 1979, 77:847-869.

10. Ueno F, Matsui T, Matsumoto T, Matsuoka K, Watanabe M, Hibi T, Guidelines Project Group of the Research Group of Intractable Inflammatory Bowel Disease subsidized by the Ministry of Health, Labour and Welfare of Japan and the Guidelines Committee of the Japanese Society of Gastroenterology: Evidence-based clinical practice guidelines for Crohn's disease, integrated with formal consensus of experts in Japan. J Gastroenterol 2013, 48:31-72.

11. Rayner CK, Hart AL, Hayward CM, Emmanuel AV, Kamm MA: Azathioprine dose escalation in inflammatory bowel disease. Aliment Pharmacol Ther 2004, 20:65-71.

12. Wang YF, Zhang $\mathrm{H}$, Ouyang $\mathrm{Q}$ : Clinical manifestations of inflammatory bowel disease: east and west differences. J Dig Dis 2007, 8:121-127.

13. Lennard-Jones JE: Classification of inflammatory bowel disease. Scand J Gastroenterol Supp/ 1989, 170:2-6.
14. Satsangi J, Silverberg MS, Vermeire S, Colombel JF: The Montreal classification of inflammatory bowel disease: controversies, consensus, and implications. Gut 2006, 55:749-753.

15. Kim DU, Kim YH, Kim BJ, Chang DK, Son HJ, Rhee PL, Kim JJ, Rhee JC: The efficacy of low dose azathioprine/6-mercaptopurine in patients with inflammatory bowel disease. Hepatogastroenterology 2009, 56:1395-1402.

16. Hibi T, Naganuma M, Kitahora T, Kinjyo F, Shimoyama T: Low-dose azathioprine is effective and safe for maintenance of remission in patients with ulcerative colitis. J Gastroenterol 2003, 38:740-746.

17. Yang CH, Ding J, Gao Y, Chen X, Yang ZB, Xiao SD: Risk factors that predict the requirement of aggressive therapy among Chinese patients with Crohn's disease. J Dig Dis 2011, 12:99-104.

18. Dewit $O$, Vanheuverzwyn $R$, Desager JP, Horsmans $Y$ : Interaction between azathioprine and aminosalicylates: an in vivo study in patients with Crohn's disease. Aliment Pharmacol Ther 2002, 16:79-85.

19. Fraser $A G$, Orchard TR, Jewell DP: The efficacy of azathioprine for the treatment of inflammatory bowel disease: a 30 year review. Gut 2002, 50:485-489.

20. Bouhnik Y, Lémann M, Mary JY, Scemama G, Taï R, Matuchansky C, Modigliani R, Rambaud JC: Long-term follow-up of patients with Crohn's disease treated with azathioprine or 6-mercaptopurine. Lancet 1996, 27:215-219.

21. Beaugerie L, Seksik P, Nion-Larmurier I, Gendre JP, Cosnes J: Predictors of Crohn's disease. Gastroenterology 2006, 130:650-656.

22. Al Hadithy AF, de Boer NK, Derijks LJ, Escher JC, Mulder CJ, Brouwers JR: Thiopurines in inflammatory bowel disease: pharmacogenetics, therapeutic drug monitoring and clinical recommendations. Dig Liver Dis 2005, 37:282-297.

23. Yip JS, Woodward M, Abreu MT, Sparrow MP: How are azathioprine and 6mercaptopurine dosed by gastroenterologists? Results of a survey of clinical practice. Inflamm Bowel Dis 2008, 14:514-518.

24. APDW2004 Chinese IBD Working Group: Retrospective analysis of 515 cases of Crohn's disease hospitalization in China: nationwide study from 1990 to 2003. J Gastroenterol Hepatol 2006, 21:1009-1015.

25. Zheng JJ, Chu XQ, Shi XH, Zhou CL, Seng BW: Efficacy and safety of azathioprine maintenance therapy in a group of Crohn's disease patients in China. J Dig Dis 2008, 9:84-88.

26. Thia KT, Li M, Ling KL, Kong SC, Ooi CJ: Azathioprine is effective in corticosteroid-dependent Asian inflammatory bowel disease patients. Inflamm Bowel Dis 2011, 17:809-815.

\section{doi:10.1186/1479-5876-11-235}

Cite this article as: Wu et al.: Low-dose azathioprine is effective in maintaining remission among Chinese patients with Crohn's disease. Journal of Translational Medicine 2013 11:235

\section{Submit your next manuscript to BioMed Central and take full advantage of:}

- Convenient online submission

- Thorough peer review

- No space constraints or color figure charges

- Immediate publication on acceptance

- Inclusion in PubMed, CAS, Scopus and Google Scholar

- Research which is freely available for redistribution 